\title{
Pengaruh Motivasi dan Lingkungan terhadap Minat Berwirausaha pada Mahasiswa STIM Pase Langsa
}

\author{
Said Yunus ${ }^{1)}$, Karnelis ${ }^{2)}$, Amirullah ${ }^{3)}$, Zulkarnain ${ }^{4)}$ \\ ${ }^{1,2,3,4)}$ Sekolah Tinggi Ilmu Manajemen Pase Langsa \\ ${ }^{1)}$ e-mail: saidyunus56@yahoo.com \\ ${ }^{2)}$ e-mail: karnelisstim048@gmail.com \\ ${ }^{3)}$ e-mail: amirullah86@yahoo.com \\ ${ }^{4)}$ e-mail: dhanishanti73@gmail.com
}

\begin{abstract}
Abstrak
Tujuan Penelitian ini adalah untuk mengetahui pengaruh motivasi dan lingkungan terhadap minat berwirausaha pada mahasiswa STIM Pase Langsa. Sampel yang digunakan sebanyak 33 responden dengan tehnik purposive sampling. Metode analisis data menggunakan uji validitas, uji reliabilitas, uji asumsi klasik, uji persamaan regresi linier berganda, uji koefisien determinasi dan uji statistic. Hasil penelitian menunjukkan bahwa motivasi dan lingkungan berpengaruh positif dan signifikan terhadap minat berwirausaha pada mahasiswa STIM Pase Langsa. Hasil uji koefisien determinasi $\left(R^{2}\right)$ diperoleh sebesar 51,2\% motivasi dan lingkungan dapat menjelaskan minat berwirausaha pada mahasiswa STIM Pase Langsa.
\end{abstract}

Kata Kunci: Motivasi, Lingkungan, Minat Berwirausaha

\section{PENDAHULUAN}

Kebutuhan menjadi alasan seseorang untuk memperoleh pendapatan dan pendapatan menjadi alasan seseorang untuk mendapatkan pekerjaan. Pekerjaan yang terbatas menjadikan alasan untuk memiliki suatu usaha yang nantinya dapat memberikan pendapatan atau penghasilan dan dapat untuk memenuhi kebutuhan. Berwirausaha juga menjadi pilihan alternatif karena keterbatasan lapangan pekerjaan, yang mana saat ini lebih banyak pencari kerja dibandingkan dengan tempat yang dapat menerima pekerja. Alasan lain adalah apabila mendapatkan pekerjaan, kemungkinan untuk memperoleh pendapatan terbatas. Terbatasnya pendapatan yaitu hanya memperoleh pendapatan secara harian, mingguan atau bulanan bahkan ada yang menerima pendapatan saat ada kegiatan pada suatu usaha dan apabila tidak ada kegiatan maka tidak memperoleh pendapatan.

Berwirausaha menjadi pilihan yang tepat karena sebenarnya irausaha sebenarnya, bila dipahami bukan sekedar mendapatkan pendapatan tetapi dapat diartikan untuk mencari kesibukan dengan adanya kegiatan yang dibangun sendiri dan bukan dari perintah atau kegiatan orang lain. Minat seseorang dalam berwirausaha dapat dikaitkan juga dengan kemauan dari dalam diri sendiri, dimana kewirausahaan dapat dikatakan sebagai kemampuan yang ada pada diri seseorang dan dapat dijadikan sebagai fundamental dalam mencapai kesuksesan (Zulkarnain \& Mukarramah, 2019). Sehingga seorang wirausaha harus memiliki motivasi dalam 
berwirausaha. Motivasi ini menjadi salah satu faktor penting dalam mendorong keberanian seseorang untuk berwirausaha, (Iswandari, 2013). Hal ini sesuai dengan penelitan sebelumnya yang dilakukan oleh (Hendrawan \& Sirine, 2017) dimana motivasi memberikan pengaruh terhadap minat berwirausaha.

Faktor motivasi menjadi faktor yang penting bagi seseorang dalam bekerja dimana pada akhirnya memperoleh dengan usaha akan mendapatkan pendapatan. Pendapatan yang memperoleh dalam memenuhi kebutuhan yang harus dipenuhi untuk kelangsungan hidup. Berwirausaha dapat memberikan pendapatan yang dapat digunakan untuk memenuhi hidupnya. Keinginan untuk memperoleh pendapatan itulah yang akan menimbulkan minat seseorang untuk berwirausaha. Selain itu yang dapat memberikan pengaruh terhadap seseorang dalam berwirausaha adalah lingkungan. Lingkungan yang ini dapat berupa lingkungan keluarga maupun lingkungan masyarakat. Lingkungan keluarga dapat memberikan dampak terhadap keinginan untuk berwirausaha serta demikian juga bahwa teman atau orang lain berdampak terhadap minat berwirausaha, (Koranti, 2013). Hal tersebut juga sesuai dengan penelitian yang dilakukan oleh (Aprilianty, 2012), dimana lingkungan memberikan pengaruh terhadap minat berwirausaha.

Minat berwirausaha saat ini ditanamkan melalui pendidikan dan salah satunya pada mahasiswa. Penanaman pengetahuan terhadap mahasiswa diharapkan nantinya mahasiswa tidak hanya berharap dapat bekerja pada instansi pemerintah maupun swasta, akan tetapi diharapkan juga dapat mendirikan sebuah usaha, sehingga dapat menampung orang lain untuk bekerja. Pada penelitian ini dilakukan pada mahasiswa Sekolah Tinggi Ilmu Manajemen Pase Langsa, dimana pada mahasiwa diberikan pengetahuan mengenai kewirausahaan. Berdasarkan survey yang dilakukan ternyata terdapat mahasiswa yang sudah memiliki usaha dengan berbagai jenis usaha. Mahasiswa ini menjalankan usaha karena termotivasi ingin memperoleh pendapatan dan tidak sepenuhnya berharap kepada orang tua. Jenis usaha yang dijalankan mulai dari industri rumahan dan juga berbinis online. Mahasiswa ini juga berwirausaha karena lingkungan keluarga dan teman yang turut mendukung usaha yang dibangun. Tetapi terdapat pula yang berwirausaha termotivasi karena pendapatan tetapi saat menjalankan usaha tidak memperoleh pendapatan bahkan merugi, dan berdampak pada motivasi yang menurun terhadap wirausaha dan akhirnya menutup atau mengganti jenis usahanya. Demikian pula keluarga terdapat keluarga yang kurang mendukung dan teman yang melecehkan atau mengejek dan hal ini dapat menurunkan minat berwirausaha mahasiswa, terutama yang baru memulai usaha. Berdasarkan hal ini terdapat hal yang menarik untuk diteliti mengenai minat berwirausaha mahasiswa Sekolah Tinggi Ilmu Manajemen Pase Langsa yang dikaitkan dengan motivasi dan lingkungan.

Penelitian ini bertujuan untuk mengetahui pengaruh dari motivasi dan lingkungan terhadap minat berwirausaha pada mahasiswa Sekolah Tinggi Ilmu Manajemen Pase Langsa.

\section{STUDI KEPUSTAKAAN}

Minat adalah perbuatan yang mengarahkan kepada suatu tujuan dan merupakan suatu dorongan bagi perbuatan itu.Dalam diri manusia terdapat dorongan-dorong (motif- 
motif) yang mendorong manusia untuk berinteraksi dengan dunia luar. Dan apa yang sudah menjadi minat seseorang mendorongnya untuk berbuat lebih giat dan lebih baik, (Purwanto, 2002). Minat juga dapat diartikan sebagai kecenderungan yang menetap pada seseorang untuk merasa tertarik pada suatu bidang tertentu dan merasa senang dalam berbagai kegiatan yang berkaitan dengan bidang itu sendiri (Winkel, 2004) dan pendapat (H, 2012) minat berhubungan dengan gaya gerak yang mendorong seseorang untuk menghadapi atau berurusan dengan orang, benda, kegiatan, pengalaman yang dirangsang oleh kegiatan itu sendiri.

Wirausaha adalah seseorang yang memiliki kemampuan dalam menggunakan dan mengombinasikan sumber daya, seperti keuangan, bahan mentah, tenaga kerja, keterampilan, dan informasi (Suryana, 2014). Sedangkan (Kasmir, 2011), wirausaha yaitu orang yang berjiwa berani mengambil resiko untuk membuka usaha dalam berbagai kesempatan.

Dengan demikian minat berwirausaha merupakan kecenderungan hati dari dalam diri individu yang mempunyai keberanian dan keinginan menciptakan suatu bidang usaha melalui ide-ide kreatif, inovatif kemudian merencanakan, mengorganisir, mengatur, menanggung resiko dan mengembangkan usaha yang diciptakannya untuk mencapai tujuan, serta dapat melihat peluang yang ada dan mampu mengelolanya dengan cara bekerja keras, semangat yang tinggi karena minat wirausaha harus melihat ke depan dalam potensi mendirikan usaha.

Motivasi dapat dibedakan menjadi dua, yaitu, (Sardiman, 2012):

1. Motivasi Intrinsik adalah motif-motif yang aktif yang fungsinya tidak perlu dirangsang dari luar.

2. Motivasi Ekstrinsik adalah motif-motif yang aktif fungsinya karena rangsangan dari luar.

Terdapat berbagai faktor yang mempangaruhi orang untuk berwirausaha, (Basrowi, 2014)yaitu:

1. Faktor Internal.

Faktor internal yaitu segenap pikiran emosi danpersoalan dari dalam diri seseorang yang mempengaruhi minat sehingga tidak dapatdipusatkan.

a. Motivasi.

Motivasi merupakan proses psikologis yang mendasar, dan merupakan salah satu unsur yang dapat menjelaskan perilaku seseorang. Motivasi merupakan salah satu faktor penentu dalam pencapaian tujuan. Motivasi berhubungan dengan dorongan atau kekuatan yang berada dalam diri manusia. Motivasi berada dalam diri manusia yang tidak terlihat dari luar. Motivasi menggerakkan manusia untuk menampilkan tingkah laku ke arah pencapaian suatu tujuan tertentu.

b. Faktor Kemampuan.

Kemampuan adalah suatu kecakapan seseorang dalam bidang tertentu, yang dapat diperoleh dari hasil belajar, melalui pendidikan formal maupun pendidikan non formal, dengan adanya kemampuan dalam berwirausaha tentu akan menimbulkan minat berwirausaha. 
c. Perasaan Senang.

Perasaan erat hubungannya dengan pribadi seseorang maka tanggapan perasaan seseorang terhadap sesuatu hal tidaklah sama antara orang yang satu dengan orang yang lain. Perasaan senang terhadap bidang wirausaha akan menimbulkan minat berwirausaha.

2. Faktor Eksternal

Faktor eksternal yaitu faktor yang berasal dari luar diri seseorang yang dapat mempengaruhi minatnya.

a. Faktor Keluarga.

Keluarga mempunyaiperan penting dalam mempersiapkan anak untuk mencapai masa depan yang baik bagi diri sendiri, keluarga, dan masyarakat,dengan adanya dorongan dari orang tua dan keluarganya dapat mempengaruhi seseorang dalam memupuk minat berwirausaha.

b. Faktor Lingkungan Masyarakat.

Faktor lingkungan yang mempengaruhi minat berwirausaha seperti lingkungan masyarakat serta nilai-nilai yang tumbuh dalam masyaratak tersebut, pergaulan dengan teman sebaya, surat kabar, televisi, danlain-lain.

c. Faktor Lingkungan Sekolah.

Sekolah merupakan lingkungan yang sangat potensial untuk mendorong peserta didik dalam perkembangan minat, misalnya di lingkungan sekolah ikut dalam mengelola Business Center, sehingga yang memiliki karakter berwirausaha, passion,dan pengalaman dapat membangun sistem usaha mandiri.

Lingkungan yang mempengaruhi berwirausaha dan menjadi lingkungan belajar dalam berwirausaha, yaitu (Slameto, 2013):

1. lingkungan sosial adalah lingkungan masyarakat baik kelompok besar atau kelompok kecil.

2. Lingkungan personal meliputi individu-individu sebagai pribadi yang berpengaruh terhadap individu pribadi lainnya.

3. Lingkungan alam (fisik) meliputi sumber daya alam yang dapat diberdayakan sebagai sumber belajar.

4. lingkungan kultural mencakup hasil budaya dan teknologi yang dapat dijadikan sumber belajar dan dapat menjadi faktor pendukung pembelajaran

\section{METODE PENELITIAN}

Penelitian dilakukan dengan menggunakan desain korelasional ex-post facto yang bertujuan mengetahui hubungan antara dua variabel dengan atau lebih dengan mengungkapkan peristiwa yang terjadi dan melihat latarbelakang dengan mengetahui faktor yang menimbulkan tanpa manipulasi variabel yang diteliti. Pendekatan penelitian dengan data kuantitatif yang diperoleh dari angka-angka secara statistik. Pengumpulan data dilakukan dengan cara observasi, wawancara dan kuesioner. 
Populasi pada penelitian ini adalah mahasiswa Sekolah Tinggi Ilmu Manajemen Pase Langsa dan dari populasi di tentukan sampel dengan tehnik purposive sampling, dimana yang menjadi pertimbangan adalah mahasiswa yang sudah menjalankan usaha dengan jumlah 33 mahasiswa. Sehingga yang menjadi sampel pada penelitian ini berjumlah 33 responden. metode analisis data menggunakan persamaan regresi linier berganda, uji koefisien determinasi $\left(\mathrm{R}^{2}\right)$ dan uji statistic (uji $\mathrm{t}$ dan uji $\mathrm{F}$ ). Sebelum dilakukan analisis data, terlebih dahulu dengan menggunakan uji validitas dan uji realibilitas serta uji asumsi klasik.

Pada penelitian ini minat berwirausaha sebagai variabel terikat diukur dengan indikator yang terdiri dari:

1. Hasrat atau keinginan

2. Perasaan bahagia

3. Terpusat pada usaha

4. Keluarga dan teman

5. Pengetahuan dari usaha sebelumnya atau orang lain

Variabel Motivasi menggunakan indikator:

1. Keuntungan

2. Kemandirian

3. Aktualiasi diri

4. Kemandirian

5. Kebutuhan

Variabel lingkungan menggunakan indikator:

1. Lingkungan internal

2. Lingkungan eksternal

\section{HASIL DAN PEMBAHASAN}

Hasil uji validitas dan reliabilitas sebagai berikut: uji validitas dilakukan dengan memberikan kuesioner kepada 30 mahasiswa lain selain responden penelitian dengan nilai $r$ tabel sebesar 0,30. Berdasarkan hasil penelitian secara keseluruhan nilai corrected item-total correlation > $\mathrm{r}$ tabel dan dinyatakan valid. Uji valid sebagai berikut:

Tabel 1. Validitas Butir Pertanyaan

\begin{tabular}{lccc}
\hline $\begin{array}{c}\text { Butir } \\
\text { Pertanyaan }\end{array}$ & $\begin{array}{c}\text { Corrected Item-Total } \\
\text { Correlation }\end{array}$ & rtabel & Ket \\
\hline Butir 1 &, 705 & 0.30 & Valid \\
Butir 2 &, 812 & 0.30 & Valid \\
Butir 3 &, 825 & 0.30 & Valid \\
Butir 4 &, 806 & 0.30 & Valid \\
Butir 5 &, 890 & 0.30 & Valid \\
Butir 6 &, 671 & 0.30 & Valid \\
\hline
\end{tabular}




\begin{tabular}{llll}
\hline Butir 7 &, 561 & 0.30 & Valid \\
Butir 8 &, 901 & 0.30 & Valid \\
Butir 9 &, 805 & 0.30 & Valid \\
Butir 10 &, 666 & 0.30 & Valid \\
Butir 11 &, 861 & 0.30 & Valid \\
Butir 12 &, 851 & 0.30 & Valid \\
Butir 13 &, 821 & 0.30 & Valid \\
Butir 14 &, 826 & 0.30 & Valid \\
Butir 15 &, 703 & 0.30 & Valid \\
\hline
\end{tabular}

Sumber: Data Primer Diolah dengan SPSS 20

Uji reliabilitas cronbach's Alpha > 0,6 dari keseluruhan butir pernyataan dinyatakan reliabel dengan cronbach alpha >0,60 atau hasil dapat dilihat pada tabel berikut.

Tabel 2. Reliabilitas Kuesioner

\begin{tabular}{lcc}
\hline \multicolumn{1}{c}{ Butir Pertanyaan } & Cronbach's Alpha & R tabel \\
\hline 5 (motivasi) & 0,851 & 0,60 \\
5 (lingkungan) & 0,821 & 0,60 \\
5 (minat berwirausaha) & 0,898 & 0,60 \\
\hline
\end{tabular}

Sumber: Data Primer Diolah dengan SPSS 20

\section{Uji Asumsi Klasik}

Uji asumsi klasik digunakan untuk mengetahui ada tidaknya normalitas residual dan heterokedastisitas pada model regresi.

1. Normalitas, uji ini dilakukan dengan menggunakan histogram, yaitu:

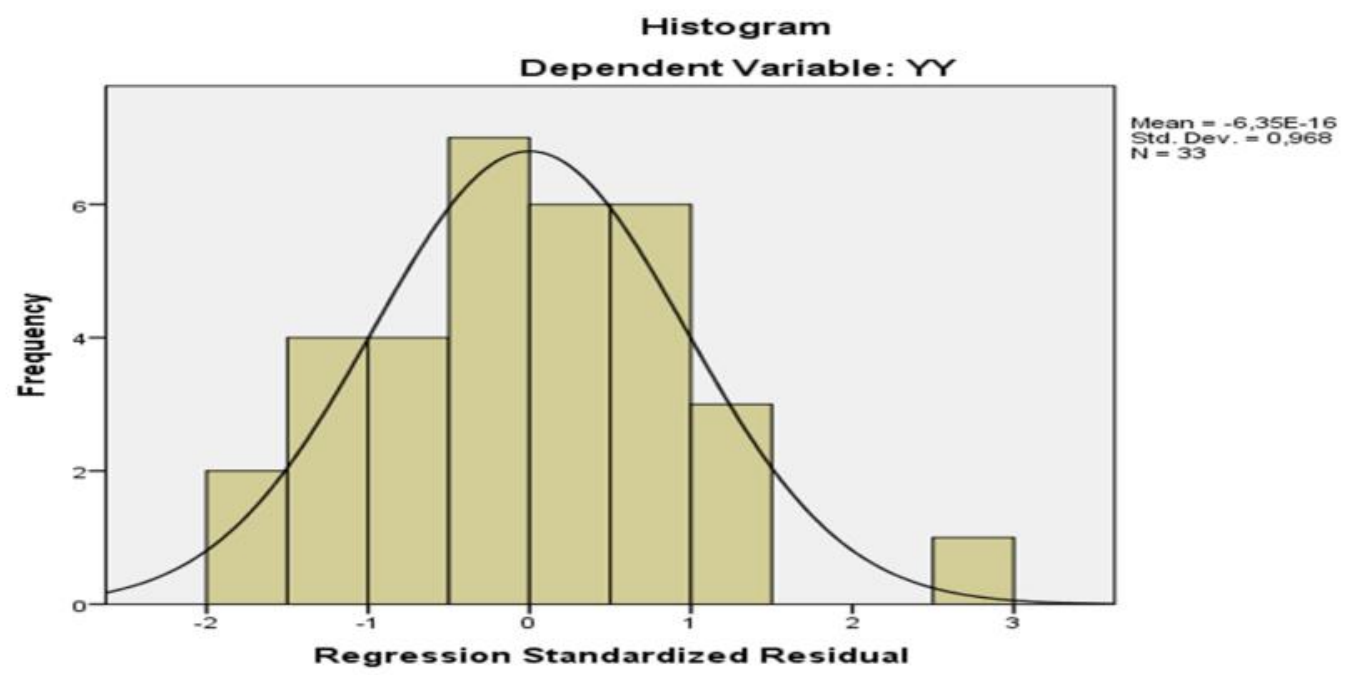

Gambar 1. Histogram

Sumber: Data Primer Diolah dengan SPSS 20 
Gambar 1. menunjukkan bahwa distribusi data menunjukkan distribusi normal dengan bentuk lonceng tidak menceng ke kiri atau ke kanan.

2. Heterokedastisitas, uji ini dilakukan dengan menggunakan grafik scatterplots.

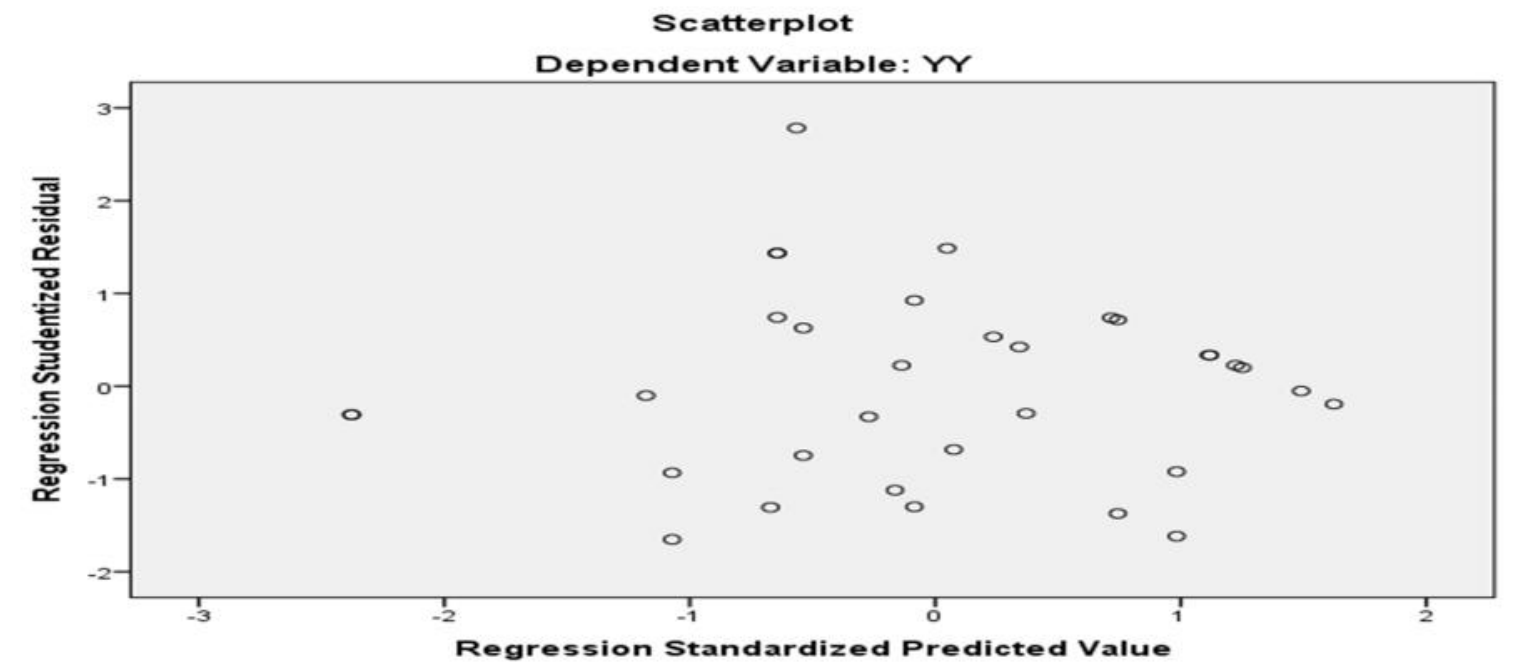

\section{Gambar 2: Scatterplots}

Sumber: Data Primer Diolah dengan SPSS 20

Gambar 2 scatterplots titik-titik tidak membentuk pola yang jelas dan titik-titik menyebar di antara titik 0 pada sumbu Y dan dapat dinyatakan tidak terjadi heterokedastisitas.

3. Multikolinearitas, uji dilakukan dengan menggunakan tabel nilai tolerance dan VIF.

Tabel 3. Uji Multikolinearitas

\begin{tabular}{llccc}
\hline Model & \multicolumn{2}{c}{ Collinearity Statistics } \\
& Tolerance & VIF & \\
1 & (Constant) & & & \\
& Motivasi &, 905 & 1,105 \\
& Lingkungan &, 905 & 1,105 \\
\hline
\end{tabular}

Sumber: Data Primer Diolah dengan SPSS 20

Berdasarkan hasil perhitungan pada tabel 3 diketahui bahwa nilai dari tolerance $>0,1$ yaitu untuk motivasi 0,905 > 0,1, lingkungan 0,905 > 0,1 serta nilai Variance Inflation Factor (VIF) $<10$, motivasi $1,105<10$, lingkungan $1,105<10$, maka dapat dinyatakan tidak terjadi multikolinearitas. 
Tabel 4. Hasil Analisis Data

\begin{tabular}{lccc}
\hline \multicolumn{1}{c}{ Variabel } & B & t - hitung & t - signifikan \\
\hline Konstanta & 1,032 & 1,782 & 0,085 \\
Motivasi & 0,550 & 5,073 & 0,000 \\
Lingkungan & 0,197 & 2,284 & 0,030 \\
$\mathrm{R}^{2}(R$ Squared $)$ & 0,512 & Predictors: (Constan), & motivasi $\quad\left(\mathrm{X}_{1}\right)$, \\
& & lingkungan $\left(\mathrm{X}_{2}\right)$ \\
$\mathrm{F}$ hitung & 15,720 & Dependent Variabel: minat berwirausaha $(\mathrm{Y})$ \\
F sig & 0,000 & & \\
\hline
\end{tabular}

Sumber: Data Primer Diolah dengan SPSS 20

Berdasarkan hasil analisis data dapat dibuat persamaan $\mathrm{Y}=1,032+0,550 \mathrm{X}_{1}+0,197 \mathrm{X}_{2}$ Persamaan dapat diintepretasikan:

a. Dapat dijelaskan bahwa minat berwirausaha bernilai positif sebesar 1,032 pada saat motivasi dan lingkungan bernilai konstan. Sementara motivasi bernilai positif sebesar 0,550 dan bila motivasi meningkat satu satuan maka akan meningkatkan minat berwirausaha pada mahasiswa sebesar 0,550 satuan dengan asumsi variabel lingkungan bernilai tetap. Lingkungan bernilai positif sebesar 0,197 dan bila lingkungan meningkat satu satuan maka akan meningkatkan minat berwirausaha mahasiswa sebesar 0,197 satuan dan variabel motivasi bernilai tetap.

b. Hasil uji koefisien determinasi $\left(\mathrm{R}^{2}\right)$ diperoleh sebesar 0,512 atau sebesar $51,2 \%$ variabel motivasi dan lingkungan dapat menjelaskan minat berwirausaha dan sebesar 48,8\% dipengaruhi oleh variabel lain yang di estimasi penelitian.

c. Hasil pengujian secara parsial (uji t) pada variabel motivasi diperoleh $\mathrm{t}$ sig $<\alpha 5 \%$ $(0,000<0,05)$ dan dapat dinyatakan motivasi berpengaruh signifikan terhadap minat berwirausaha mahasiswa. Pada variabel lingkungan diperoleh $t$ sig $<\alpha 5 \%(0,030<0,05)$ dan dapat dinyatakan lingkungan berpengaruh signifikan terhadap minat berwirausaha mahasiswa.

d. Hasil pengujian secara simultan (uji F) diketahui nilai Fsig 0,000, Karena nilai Fsig lebih kecil dibandingkan tingkat signifikansi, yakni 0,05, maka pengaruh simultan dari variabel bebas motivasi dan lingkungan terhadap minat berwirausaha mahasiswa signifikan.

\section{Pengaruh Motivasi terhadap Minat Berwirausaha}

Berdasarkan hasil penelitian diketahui bahwa motivasi berpengaruh positif dan signifikan terhadap minat berwirausaha mahasiswa Sekolah Tinggi Ilmu Manajemen Pase Langsa, Pengaruh motivasi terhadap minat berwirausaha ini lebih dominan dengan nilai koefisien sebesar 0,550, hal ini dikarenakan dengan termotivasinya mahasiswa untuk memperoleh pendapatan dan juga karena adanya keinginan untuk memiliki usaha atau pekerjaan. Kemudian dengan adanya usaha menunjukkan bahwa mahasiswa juga dapat mandiri dan berhasil tanpa harus meminta pekerjaan pada pihak lain. Mandiri dalam hal pengaturan usaha, pembagian laba dan menanggung kerugian. 


\section{Pengaruh Lingkungan Terhadap Minat Berwirausaha}

Berdasarkan hasil pengujian diketahui pengaruh parsial dari variabel lingkungan berpengaruh positif dan signifikan secara statistik terhadap minat berwirausaha mahasiswa, maka disimpulkan pengaruh parsial signifikan secara statistik dikarenakan oleh adanya pengaruh yang kuat dari dalam lingkuan keluarga terutama orang tua yang memberikan dukungan terhadap usaha yang dilakukan oleh anak. Kemudian lingkungan teman yang memberikan dukungan berupa masukan-masukan perbaikan dalam menjalankan usaha serta mau mendukung dengan cara membeli atau menggunakan produk wirausaha, sehingga minat berwirausaha mahasiswa ini didukung positif oleh lingkungan.

\section{PENUTUP}

Kesimpulan yang diperoleh berdasarkan hasil penelitian adalah sebagai berikut:

1. Motivasi dan lingkungan berpengaruh positif terhadap minat berwirausaha mahasiswa Sekolah Tinggi Ilmu Manajemen Pase Langsa.

2. Motivasi dan lingkungan secara parsial dan simultan berpengaruh signifikan terhadap minat berwirausaha mahasiswa Sekolah Tinggi Ilmu Manajemen Pase Langsa.

\section{REFERENSI}

Aprilianty, E. 2012. Pengaruh Kepribadian Wirausaha, Pengetahuan Kewirausahaan, dan Lingkungan Terhadap Minat Berwirausaha Siswa SMK. Jurnal Pendidikan Vokasi, 2(3).

Basrowi. 2014. Kewirausahaan untuk Perguruan Tinggi. Bogor: Ghalia Indonesia. H, D. 2012. Psikologi Pendidikan. Jakarta: PT. Bumi Aksara.

Hendrawan, J. S., \& Sirine, H. 2017. Pengaruh Sikap Mandiri, Motivasi, Pengetahuan Kewirausahaan terhadap Minat Berwirausaha (Studi Kasus pada Mahasiswa FEB UKSW Konsentrasi Kewirausahaan). AJIE- Asian Journal of Innovation and Enterpreneurship, 02(03).

Iswandari, A. 2013. Pengaruh Motivasi Intrinsik, Pengetahuan Kewirausahaan, dan Kepribadian Terhadap Minat Berwirausaha pada Siswa SMKN 12 Surabaya. Jurnal Ekonomi Pendidikan Dan Kewirausahaan, 1(2).

Kasmir. 2011. Kewirausahaan. Jakarta: PT. RajaGrafindo Persada.

Koranti, K. 2013. Analisis Pengaruh Faktor Eksternal dan Internal terhadap Minat Berwirausaha.

Proceeding PESAT (Psikologi, Ekonomi, Sastra, Arsitektur \& Teknik Sipil), 5.

Purwanto, N. 2002. Psikologi Pendidikan. Bandung: PT. Remaja Rosdakarya.

Sardiman. 2012. Interaksi dan Motivasi belajar. Jakarta: Raja Grafindo.

Slameto. 2013. Belajar dan Faktor yang Mempengaruhinya. Jakarta: Indeks.

Suryana. 2014. Kewirausahaan. Jakarta: Salemba Empat.

Winkel. 2004. Psikologi Pengajaran. Yogyakarta: Andi Offset.

Zulkarnain, M., \& Mukarramah. 2019. Pengaruh Orientasi Kewirausahaan dan Orientasi Pasar 
Terhadap Kinerja UMKM Sektor Makanan dan Minuman. Jurnal Akuntansi, Ekonomi Dan Manajemen Bisnis, 7(2), 192-200. 